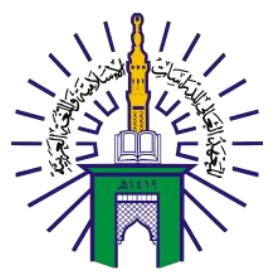

BUSTANUL FUQAHA:

JURNAL BIDANG HUKUM ISLAM

Vol. 2 No. 1 (2021): Hal. 98-109

EISSN: 2723-6021

Website: https://journal.stiba.ac.id

\title{
SANKSI HUKUMAN MATI TERHADAP PEMBUNUHAN NON-MUSLIM (STUDI KOMPARATIF IMAM ABŪ ḤANĪFAH DAN IMAM AL-SYĀFI'Ī)
}

\section{DEATH PENALTY FOR KILLING NON-MUSLIMS (COMPARATIVE STUDY PRIEST ABU Ü HANIFFAH AND PRIEST AL-SYĀFI'I)}

\author{
Iskandar \\ Sekolah Tinggi Ilmu Islam dan Bahasa Arab (STIBA) Makassar \\ iskandarkato@stiba.ac.id \\ Ariesman \\ Sekolah Tinggi Ilmu Islam dan Bahasa Arab (STIBA) Makassar \\ ariesman@stiba.ac.id \\ Iman Afandi \\ Sekolah Tinggi Ilmu Islam dan Bahasa Arab (STIBA) Makassar \\ imafandibs@gmail.com
}

\begin{tabular}{|c|c|}
\hline Keywords : & ABSTRACT \\
\hline $\begin{array}{l}\text { Death Penalty Sanctions, } \\
\text { Murder of Non-Muslims }\end{array}$ & 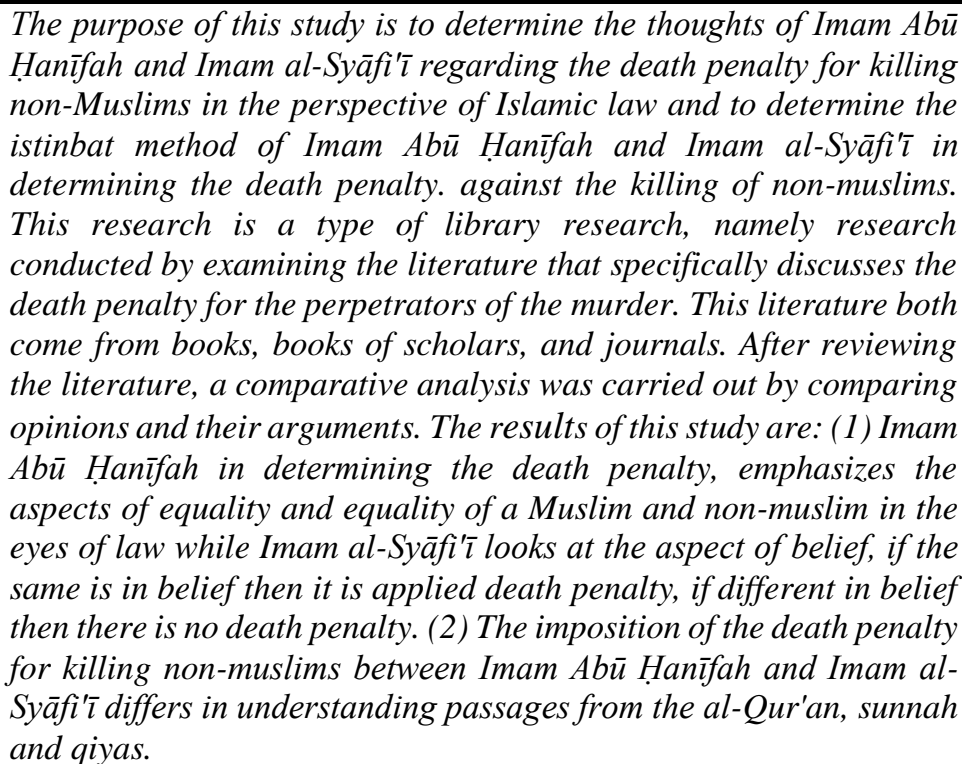 \\
\hline \multirow{2}{*}{$\begin{array}{l}\text { Kata kunci : } \\
\text { Sanksi Hukuman Mati, } \\
\text { Pembunuhan Non-Muslim, }\end{array}$} & ABSTRAK \\
\hline & $\begin{array}{l}\text { Tujuan penelitian ini untuk mengetahui pemikiran Imam Abū } \\
\text { Hanīfah dan Imam al-Syāfi'î tentang sanksi hukuman mati terhadap } \\
\text { pembunuhan terhadap non-muslim dalam perspektif hukum Islam } \\
\text { dan untuk mengetahui metode istinbat Imam Abū Hanīfah dan Imam } \\
\text { al-Syāfi' } \overline{1} \text { dalam menetapkan sanksi pidana mati terhadap } \\
\text { pembunuhan non-muslim. Penelitian ini merupakan jenis penelitian } \\
\text { kepustakaan (library research), yakni penelitian yang dilakukakan } \\
\text { dengan mengkaji literatu-literatur yang khusus membahas tentang }\end{array}$ \\
\hline
\end{tabular}

Iskandar, Ariesman, Iman Afandi. Sanksi Hukuman Mati ... 


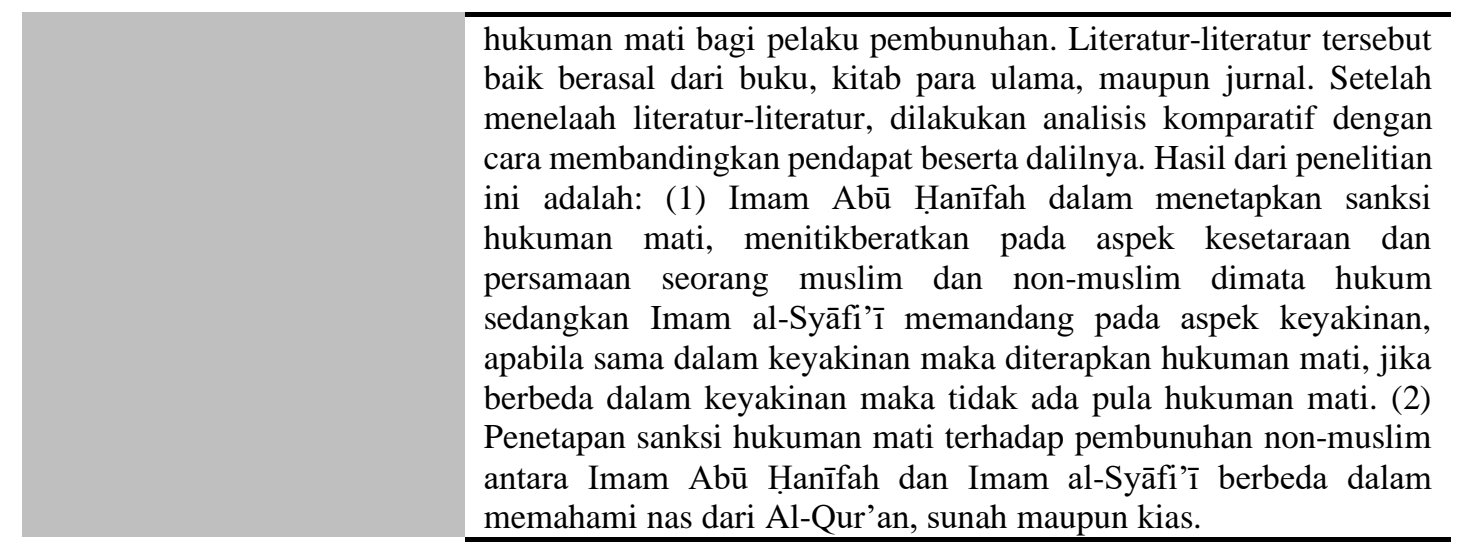

Diterima: 5 April 2021; Direvisi: 8 April 2021; Disetujui: 21 April 2021; Tersedia online: 23 April 2021

How to cite: Iskandar, Ariesman and Iman Afandi, "Sanksi Hukuman Mati Terhadap Pembunuhan Non-Muslim (Studi Komparatif Imam Abū Ḥanīfah dan Imam al-Syāfi'î)." BUSTANUL FUQAHA: Jurnal Bidang Hukum Islam 2, No.1 (April, 23, 2021): 98-109. doi: https://doi.org/10.36701/bustanul.v2i1.311

\section{PENDAHULUAN}

Tujuan utama disyariatkannya hukum Islam adalah untuk melindungi kemaslahatan manusia, baik kemaslahatan individu maupun masyarakat. Maslahat tersebut tercakup dalam al-Dharuriyat al-Khamsah yang merupakan lima kebutuhan penting yang harus dijaga oleh kaum muslimin, terdiri dari hifz al- 'Aql (menjaga akal), hifz al-Nasl (menjaga keturunan), hifz al-Nafs (menjaga jiwa), hifz al-Dīn (menjaga agama), dan hifz al-Māl (menjaga harta) ${ }^{1}$.

Dalam sejarah peradaban manusia, jenis kejahatan yang pertama kali muncul adalah tindakan pembunuhan. Hal ini dapat dilihat secara jelas dalam Al-Qur'an tentang sejarah kedua putera Adam yaitu Qobil dan Habil yang dijelaskan dalam Qs. AlMaidah/5:28-30,

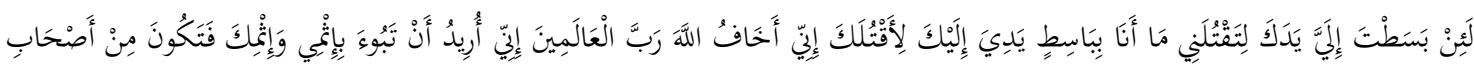

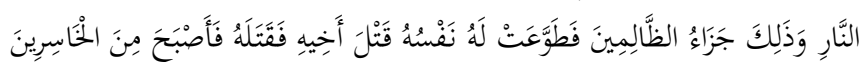

Terjemahnya:

"Sungguh, jika engkau (Qabil) menggerakkan tanganmu kepadaku untuk membunuhku, aku tidak akan menggerakkan tanganku kepadamu untuk membunuhmu. Sesungguhnya aku takut kepada Allah, Tuhan seluruh alam. Sesungguhnya aku ingin agar engkau kembali dengan (membawa) dosa (membunuh)ku dan dosamu sendiri, maka engkau akan menjadi penghuni neraka, dan yang demikian itulah pembalasan bagi orang-orang yang zalim. Maka nafsu

${ }^{1}$ Muhammad 'Alī al-Șābūnī, Rawāi' al-Bayān Tafsīr Āyāt al-Aḥkām, Juz 2, Cet. I (Damaskus: Maktabah al-Ghazālī, 1980), 52. 


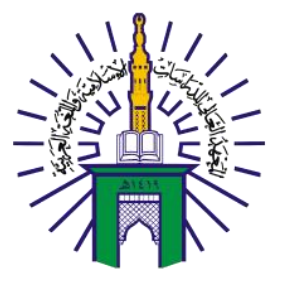

\section{BUSTANUL FUQAHA: \\ JURNAL BIDANG HUKUM ISLAM \\ Vol. 2 No. 1 (2021): Hal. 98-109 \\ EISSN: 2723-6021 \\ Website: https://journal.stiba.ac.id}

(Qabil) mendorongnya untuk membunuh saudaranya, kemudian dia pun (benarbenar) membunuhnya, maka jadilah dia termasuk orang yang rugi ${ }^{2}$.

Pembunuhan merupakan suatu tindak kejahatan menghilangkan nyawa orang lain, dan agama Islam termasuk agama yang paling menjaga hak-hak manusia, mengecam tindakan tersebut. Dalam hal ini Allah swt. berfirman dalam Qs. Al-Isrā'/17: 33.

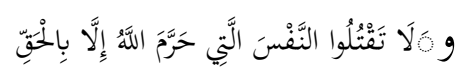

Terjemahnya:

"Dan janganlah kamu membunuh orang yang diharamkan Allah (membunuhnya), kecuali dengan alasan yang benar"3.

Salah satu dari ajaran Islam adalah memperhatikan dan menghormati hak hidup manusia, baik muslim maupun non-muslim. Islam menyamakan kedudukan kaum muslim dengan kaum żimmī, yaitu orang kafir yang berlindung dibawah kekuasaan negara Islam, dalam kehidupan sosial dan politik sedangkan dalam bidang akidah tidak boleh ada persamaan sama sekali, juga tidak boleh toleransi. Dalam hal ini Islam telah menarik garis nyata antara kaum muslim dan orang-orang kafir ${ }^{4}$.

Dalam kehidupan bermasyarakat kaum muslim dan kaum żimmī hidup berdampingan sebagai warga negara. Untuk itu, bagi kaum muslim hendaknya menjaga hak serta menghormati hak hidup mereka untuk tinggal di lingkungan kaum muslim dengan aman. Pembunuhan yang dilakukan orang muslim terhadap orang żimmī adalah pelanggaran terhadap perjanjian perlindungan dan hak asasi manusia yang dihormati oleh Islam. Pemberian sanksi merupakan konsekuensi hukum yang harus diberikan kepada pelakunya sebagai wujud persamaan antara orang muslim dan orang żimmī dari segi politik dan hukum.

Jumhur ulama, salah satunya Imam Al-Syāfi'ī berpendapat bahwa orang muslim yang membunuh orang non muslim tidak diberlakukan baginya pembunuhan. Berdasarkan dalil dari sebuah hadis yang diriwayatkan dari 'Alī, sesungguhnya ia ditanya oleh Qais bin 'Ubādah dan al-Asytar, “Apakah Rasulullah saw. pernah memberikan kepadamu suatu pesan yang tidak pernah dipesankan kepada orang lain?" 'Alī menjawab, "Tidak, kecuali yang ada dalam catatanku ini." Kemudian ia mengeluarkan sebuah catatan dari sarung pedangnya. Isinya adalah berikut:

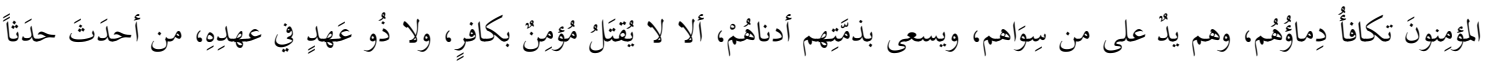

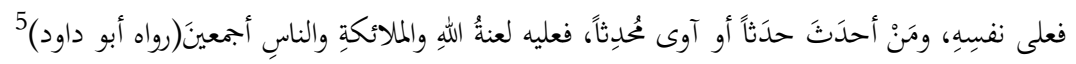

${ }^{2}$ Kementerian Agama Republik Indonesia, Al-Qur'an Terjemah Perkata Asbabun Nuzul dan Tafsir Bil Hadis (Bandung: Semesta Al-Qur'an, 2013), 112.

${ }^{3}$ Kementerian Agama Republik Indonesia, 285.

${ }^{4}$ A. Hasjmy, Dimana Letak Negara Islam, Cet. I (Surabaya: P.T. Bina Ilmu, 1984), 222.

5 Abu Dāwud Sulaimān bin al-Asy’as̀ bin Isḥāq al-Sijistān̄i, Sunan Abī Dāwud, Juz 6, Cet. I (t.t.p.: Dār al-Risālah al-'Ālamiyyah, 2009), 587. 


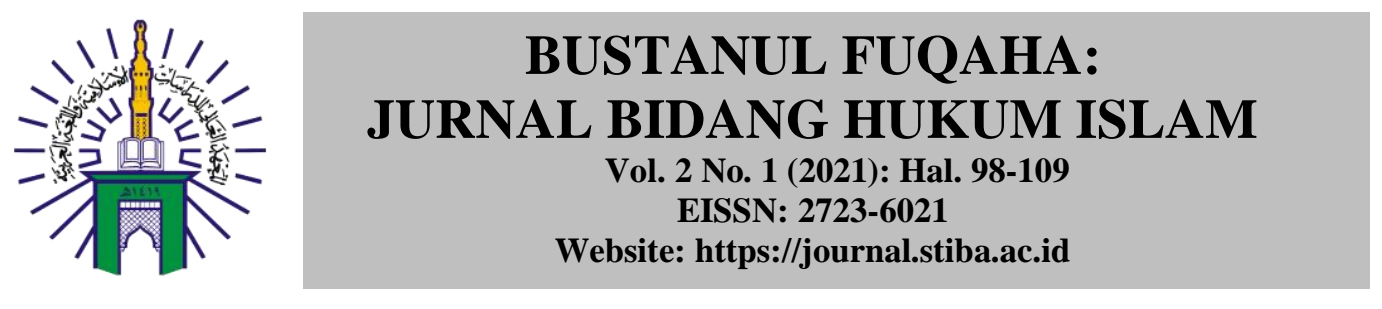

\section{BUSTANUL FUQAHA}

Jurnal Bidang Hukum Islam

Artinya:

Kaum beriman itu sama darahnya. Yang paling rendah di antara mereka berusaha menuntut jaminan mereka. Dan mereka adalah satu tangan atas orang-orang selain mereka. Bahwa seorang mukmin tidak dihukum mati karena membunuh orang kafir dan janganlah membunuh orang kafir yang memiliki perjanjian damai dalam masa perjanjiannya yang masih berlaku. Barangsiapa yang mengada-adakan sesuatu atau melindungi yang mengada-adakan sesuatu, maka ia terkena laknat Allah, para malaikat, dan seluruh manusia.

Adapun Abū Ḥanīfah berpendapat bahwa seorang muslim yang membunuh orang kafir diberi hukuman mati. Berdasarkan pada hadis yang diriwayatkan oleh Rubai'ah bin Abdurrahman al-Salmānī, berkata:

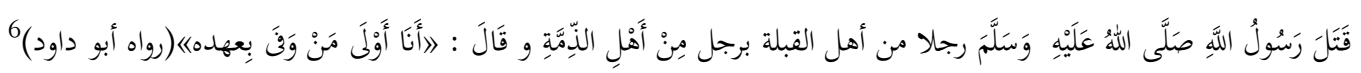

Artinya:

Rasulullah saw. menghukum mati seorang laki-laki dari ahli kiblat (Islam) karena membunuh seorang laki-laki dari kaum żimmī, dan beliau bersabda, "Aku adalah orang yang paling setia memenuhi janjinya.

Dari segi kias, para ulama mazhab Hanafi mengacu pada ijmak kaum muslimin bahwa tangan seorang muslim dipotong jika mencuri harta dari orang żimmī. Mereka berkata, jika kehormatan hartanya sama dengan kehormatan harta kaum muslimin, maka kehormatan darahnya sama dengan kehormatan darah kaum muslimin?

Berdasarkan penjelasan di atas, terjadi perbedaan pemikiran dan metode istinbat antara Imam al-Syāfi' '̄ dan Imam Abu Hanīfah dalam masalah pembunuhan orang non muslim yang dilakukan oleh seorang muslim. Rumusan masalah penelitian ini adalah: 1) Bagaimana pemikiran Imam Abū Hanīfah dan Imam al-Syāfi’’̄ tentang sanksi hukuman mati terhadap pembunuhan non-muslim?; 2) Bagaimana metode istinbat hukum kedua Imam dalam menetapkan sanksi bagi pembunuhan tersebut?. Adapun tujuan penelitian adalah untuk mengetahui pemikiran Imam Abū Hanīfah dan Imam al-Syāfi'̄ī tentang sanksi hukuman mati terhadap pembunuhan terhadap non muslim dalam perspektif hukum Islam dan untuk mengetahui metode istinbat Imam Abū Hanīfah dan Imam AlSyāfi'î dalam menetapkan sanksi pidana mati terhadap pembunuhan non-muslim.

Penelitian ini termasuk jenis penelitian kepustakaan (library research) yaitu dengan mencari dan menelaah literatur-literatur yang berhubungan dengan penelitian ini ${ }^{8}$. Metode pendekatan yang digunakan dalam penelitian ini adalah yuridis normatif, yaitu pendekatan yang dilakukan dengan meneliti bahan pustaka atau data sekunder sebagai

${ }^{6}$ Abu Dāwud Sulaimān bin al-Asy’as bin Ishāa al-Sijistān̄̄, al-Marās̄̄l, Cet. I (Bairūt: Muassasah al-Risālah, 1408), 207.

${ }^{7}$ Muhammad bin Aḥmad bin Rusyd al-Qurtubī, Bidāyat al-Mujtahid wa Nihāyat al-Muqtasid, (Cet. I. al-Qāhirah: Dār al-‘Ālamiyyah, 2016), 938-939.

${ }^{8}$ Jusuf Soewadji, Pengantar Metodologi Penelitian, (Jakarta: Mitra Wacana Media, 2012), 59. 
bahan dasar untuk diteliti dengan cara mengadakan penelusuran terhadap hukum dan literatur-literatur yang berkaitan dengan permasalahan yang diteliti serta melacak pembenarannya melalui dalil-dalil Al-Qur'an dan hadis Nabi saw. serta pendapat para ulama ${ }^{9}$. Bahkan, menelaah literasi yang memuat pendapat Abū Hanīfah dan Al-Syāfi' '̄ untuk mendapatkan data mengenai bagaimana sanksi hukuman mati terhadap pembunuhan non muslim studi komparatif antara Imam Abū Hanīfah dan Imam AlSyāfi'ī .

Di antara referensi dalam membantu menjelaskan penelitian ini adalah: 1) Kitab al-Mabsūt merupakan karya dari Muhammad bin Ahmad bin Abi Sahl al-Sarkhasī (wafat 483 H.). Kitab ini merupakan kitab fikih dalam mazhab Hanafi, yang mencakup seluruh bab dalam fikih dengan metode penulisan yang mudah serta perumpamaan yang jelas. Ditulis pula didalamnya mengenai hukum, dalil serta perbandingan mazhab selainnya, khususnya mazhab Syafi'i dan mazhab Maliki. Terkadang disebutkan mazhab Imam Ahmad dan az-Zāhiriyyah. Dalam kitab ini fokus pada pembahasan tentang Jināyāt dan Hudūd; 1) Kitab Al-Umm karangan al-Syāfi' '̄ Abu 'Abdillah Muḥammad bin Idrīs bin al- 'Abbās bin 'Us̉mān bin Syāfí' bin Mutțalib bin 'Abd Manāf al-Muț̣alibī al-Qurasyī alMakkī (wafat 204 H.). Kitab ini membahas tentang fikih, dan setiap babnya dibuka dengan menyebutkan ayat atau hadis. Dalam kitab ini fokus pada pembahasan tentang Jināyāt dan Hudüd kepada muslim yang membunuh Zimmī.

Dengan demikian, penelitian ini memiliki keistimewaan dibanding penelitian sebelumnya karena berisi studi komparatif antara dua mazhab besar, yakni mazhab Hanafi dan mazhab Syafi'i yang dibahas secara rinci. Pemilihan komparatif dua mazhab ini dalam sanksi hukuman mati terhadap pembunuhan non muslim karena kedua mazhab inilah yang memiliki pendapat kontradiktif dibanding dua mazhab selainnya.

\section{PEMBAHASAN}

\section{Pendapat Imam Abū Hanīfah tentang Sanksi Hukuman Mati terhadap Pembunuhan Non-Muslim}

Sanksi pidana dalam syariat Islam ada beberapa bentuk. Selain 'Uqūbah hād (hukuman had) dan kisas terdapat pula macam 'Uqübah lainnya, yang bersesuaian dengan jiwa manusia seperti, hukuman Ta'zir, kafarat dan lain-lain. Hal ini membantu para hakim dalam melaksanakan sanksi pidana dan memberi kepada tiap keadaan sanksi yang sepadan. Adapun tujuan penerapan sanksi, adalah untuk memperbaiki jiwa dan mendidiknya serta berusaha mewujudkan ketentraman bahkan keamanan bagi masyarakat. Kemudian dalam penerapan hukuman mati, syariat Islam tidak menghalanginya sama sekali, tetapi di samping itu, Islam mengadakan beberapa syarat

${ }^{9}$ Soejono Soekanto dan Sri Mamudji, Penelitian Hukum Normatif: Suatu Tinjauan Singkat (Jakarta: Rajawali pers, 2001), 13-14. 


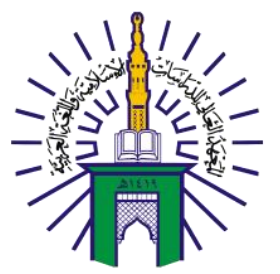

\section{BUSTANUL FUQAHA: \\ JURNAL BIDANG HUKUM ISLAM \\ Vol. 2 No. 1 (2021): Hal. 98-109 \\ EISSN: 2723-6021 \\ Website: https://journal.stiba.ac.id}

yang sangat selektif untuk menyempitkan pelaksanaan hukuman tersebut dan memberikan keringanan apabila ada maaf dari pihak yang terbunuh ${ }^{10}$.

Mazhab Hanafi menjelaskan bahwa seseorang yang membunuh orang lain tanpa alasan merupakan kejahatan yang paling besar setelah syirik kepada Allah swt. ${ }^{11}$, sebagaimana dalam Al-Qur'an surat Al-Mā'idah/5:32,

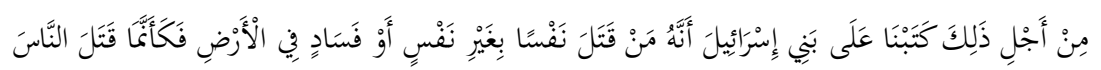

Terjemahnya:

"Oleh karena itu Kami tetapkan (suatu hukum) bagi Bani Israil, bahwa barang siapa yang membunuh seorang manusia, bukan karena orang itu (membunuh) orang lain, atau bukan karena membuat kerusakan di muka bumi, maka seakanakan dia telah membunuh manusia seluruhnya"12.

Pembunuhan pertama kali yang dilakukan oleh umat manusia menjadi sebab ditetapkannya suatu hukum dalam ayat tersebut. Hukum ini bukanlah ditetapkan kepada Bani Israil saja, tetapi ditetapkan untuk semua manusia. Tidak dibolehkan bagi siapa saja membunuh orang lain tanpa alasan seperti membunuh bukan karena kisas dan bukan karena berbuat kerusakan di bumi seperti murtad, zina setelah menikah, membajak jalan (Qat'u Al-Tharìq) dan sebagainya. Ayat tersebut menunjukkan bahwa membunuh hanya dibolehkan dalam dua hal saja, yaitu:

1. Karena seseorang membunuh satu jiwa tanpa alasan yang benar dan dengan sengaja, maka pembunuhnya halal dibunuh, jika si pembunuh sudah mukallaf (balig dan berakal) dan bukan sebagai bapak bagi si terbunuh;

2. Karena mengadakan kerusakan di bumi, misalnya merusak agama, menyakiti badan manusia atau hartanya, seperti orang murtad dan pembajak ${ }^{13}$.

Allah Ta'ala memandang bahwa membunuh seseorang seperti membunuh manusia seluruhnya, karena seseorang adalah anggota masyarakat dan karena membunuh seseorang berarti membunuh juga keturunannya. Demikian juga karena membunuh tanpa alasan yang dibenarkan menunjukkan bahwa ia tidak membedakan antara orang yang dibunuh itu dengan orang yang lainnya yang tidak bersalah, dan menunjukkan tindakan yang dilakukannya didorong oleh hawa nafsunya yang menyuruh kepada keburukan, oleh karenanya ketika ia membunuhnya sama saja ia membunuh manusia semuanya.

Abū Ḥanīfah dan beberapa ulama yang lain berpendapat bahwa seorang muslim yang membunuh kafir żimmī dengan sengaja dan tidak mendapatkan pengampunan dari pihak keluarga yang terbunuh, maka diberlakukan baginya hukuman mati. Berdasarkan

53.

${ }^{10}$ Hasbi Shiddiqi, Pidana Mati dalam Syari'at Islam (Semarang: Pustaka Rizki Putra, 1998), 52-

${ }^{11}$ Muḥammad bin Aḥmad al-Sarkhas̄î, al-Mabsūt, Jilid 26 (Beirut: Dār al-Ma’rifah, 1993), 58-59.

12 Kementerian Agama Republik Indonesia, 113.

${ }^{13}$ Abu Yahya Marwan bin Musa, Hidāyat al-Insān bi Tafsīr al-Qur'ān, Jilid 1 (t.t.p.; t.t.), 352. 


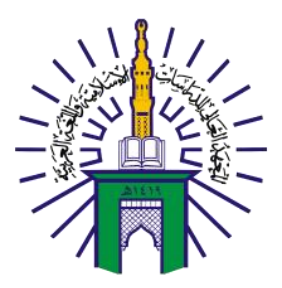

\section{BUSTANUL FUQAHA: \\ JURNAL BIDANG HUKUM ISLAM \\ Vol. 2 No. 1 (2021): Hal. 98-109 \\ EISSN: 2723-6021 \\ Website: https://journal.stiba.ac.id}

dalil Al-Qur'an yang menjelaskan secara umum bahwa setiap pembunuhan yang dilakukan, maka berlaku baginya hukum kisas. Allah swt. berfirman dalam surat AlBaqarah/2:178,

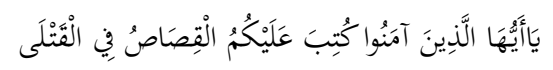

Terjemahnya:

"Wahai orang-orang yang beriman, diwajibkan atas kalian (melaksanakan) kisas berkenaan dengan orang yang dibunuh"14.

Pendapat Imam Abū Hanīfah diperkuat oleh hadis Rasulullah saw. yang diriwayatkan oleh Rubai'ah bin Abdurrahman as-Salmānī:

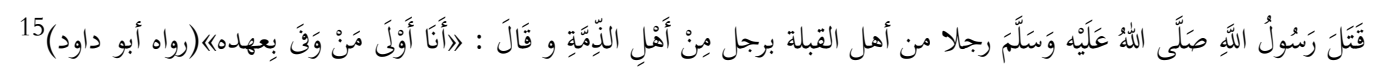

Artinya:

Rasulullah saw. menghukum mati seorang laki-laki dari ahli kiblat (Islam) karena membunuh seorang laki-laki dari kaum żimmī, dan beliau bersabda, Aku adalah orang yang paling setia memenuhi janjinya.

Ulama Mazhab Hanafi sepakat bahwa seorang muslim yang melakukan pembunuhan terhadap kafir żimmī, yakni orang-orang kafir yang membayar upeti dan berlaku bagi mereka hukum-hukum Islam, maka diberlakukan hukum kisas terhadap si pembunuh. Adapun seorang muslim yang membunuh orang kafir selain żimmī, maka tidak ada hukum kisas bagi si pembunuh, meskipun mereka meminta keamanan di lingkungan orang-orang Islam, dan mempunyai perjanjian baik dengan ikrar maupun dokumen. Mereka tetap dihukumi sebagai kafir ḩarbī, tidak berlaku bagi mereka hukumhukum Islam sebagaimana yang berlaku terhadap żimmi.

Islam dalam pelaksanaan hukum kisas bersandar pada persamaan kedudukan sebagaimana seorang ayah yang membunuh anaknya tidak dikisas dan beberapa kasus lainnya. Oleh karena itu, seorang kafir żimmī yang membunuh sesama żimmī maka berlaku hukuman mati terhadap pembunuh. Ketika seorang żimmī dibunuh oleh seorang muslim maka berlaku baginya hukum mati dikarenakan mereka sama dalam hal peraturan yang diterapkan di lingkungan Islam baik dari segi politik dan hukum.

Penerapan upeti atau pajak dari orang żimmī, Alī ra. berkata, bahwasannya jizyah itu diambil untuk menjadikan darah orang-orang non muslim sama seperti darah orang muslim (haram dibunuh), dan harta-harta mereka sama dengan harta-harta orang muslim. Selain itu, aturan ini menjadikan orang żimmī sama dengan orang muslim, dan oleh sebab itu pula berlaku hukum potong tangan bagi seorang muslim yang mencuri harta orang-

\footnotetext{
${ }^{14}$ Kementerian Agama Republik Indonesia, 27.

15 Abu Dāwud Sulaimān bin al-Asy’as̉ bin Ishāa al-Sijistān̄̄, al-Marās̄̄l, 207.
} 
orang żimm $\imath^{-16}$. Pendapat ini mengacu pada ijmak kaum muslimin, dan jika kehormatan hartanya sama dengan kehormatan harta kaum muslim, maka kehormatan darahnya sama dengan kehormatan darah kaum muslimin. Inilah dalil kias yang membuat Abū Hanīfah dan beberapa ulama lainnya berpendapat bahwa seorang muslim yang membunuh kafir żimmī dengan sengaja dan tanpa alasan, maka berlaku baginya kisas atau hukuman mati.

\section{Pendapat Imam Al-Syāfi'ī tentang Sanksi Hukuman Mati terhadap Pembunuhan Non-Muslim}

Pembunuhan yang dilakukan oleh seorang muslim secara sengaja terhadap non muslim, baik itu harbī atau żimmī, maka tidak ada sanksi kisas yang diterapkan. Ini termasuk pendapat jumhur, Imam Malik, Imam al-Syāfi'ī dan Imam Ahmad. Berbeda dengan yang lainnya, Imam Malik mengecualikan pembunuhan yang dilakukan secara sadis seperti memutilasi dan menyembelih korban ${ }^{17}$. Jumhur termasuk Imam al-Syāfi' $\overline{1}$ berpendapat berdasarkan nas dari Al-Qur'an dan sunah bahwa seorang muslim tidak dibunuh karena telah membunuh non muslim. Dalam hal ini Imam al-Syāfi' $1 \overline{1}$ memandang pada persamaan kedudukan serta aspek keyakinan. Allah swt. berfirman dalam surat AlBaqarah/2:178,

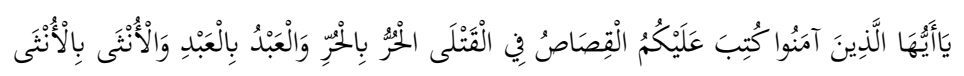

Terjemahnya:

"Wahai orang-orang yang beriman, diwajibkan atas kalian (melaksanakan) kisas berkenaan dengan orang yang dibunuh. Orang merdeka dengan orang merdeka, budak dengan budak, dan wanita dengan wanita"18.

Allah swt. telah memberikan karunia kepada hamba-hamba-Nya yang beriman dengan mewajibkan atas mereka menegakkan kisas berkenaan dengan orang-orang yang terbunuh, yakni memberikan hukuman yang sama, di mana pelaku pembunuhan dibunuh dengan model pembunuhan yang ia lakukan terhadap orang yang dibunuhnya, sebagai bentuk penegakan keadilan dan kesetaraan antara manusia ${ }^{19}$. Kesetaraan dan persamaan status menjadi syarat diberlakukannya kisas terhadap pembunuhan yang dilakukan dengan sengaja. Orang merdeka dibunuh dengan orang merdeka, budak dibunuh dengan budak, dan wanita dibunuh dengan wanita ${ }^{20}$. Imam al-Syāfi' '̄ mengemukakan pendapat bahwa seorang mukmin laki-laki dan perempuan, baik budak maupun orang merdeka, tidaklah dipidana mati untuk selama-lamanya dengan sebab membunuh orang kafir dalam keadaan bagaimanapun. Semua orang yang memiliki sifat iman, baik yang lemah akal

16 'Usjmān bin 'Alī bin Mahjan al-Bāri'ī; Fakhruddin al-Zayla'̄i al-Ḥanafī, Tabyīn al-Haqāiq Syarḥu Kanz al-Daqāiq, Jilid 6, Cet. I (Kairo: al-Mathba’ah al-Kubrā al-Amīriyyah, 1313 H), 102-103.

${ }^{17}$ Muhammad bin Ahmad bin Rusyd al-Qurtubī, 938.

${ }^{18}$ Kementerian Agama Republik Indonesia, 27.

19 'Abdurrahmān bin Nāṣir bin 'Abdullah al-Sa'dī, Tais̄̄r al-Karīm al-Raḥmān fì Tafsīr Kalām alMannān Cet. I (Beirut: Muassasah al-Risālah, 2000), 84.

${ }^{20}$ Pilihan Para Ulama Tafsir, al-Tafsìr al-Muyassar, Cet. II (Saudi Arabia: Majma' al-Mulk Fahd li Ṭibā'ah al-Muṣhaf al-Syarīf, 2009), 27. 
maupun yang bisu namun dapat memahami atau memberi isyarat tentang keimanan dengan salat lalu ia membunuh orang kafir, maka tidak ada kisas atasnya, namun ia harus membayar diat yang diambil dari hartanya ${ }^{21}$.

Seorang muslim yang melakukan pembunuhan terhadap non muslim tidak dikisas, namun tetap mendapatkan hukuman berupa penahanan yang durasinya tidak sampai satu tahun dan tidak sampai pada tingkat hukuman mati ${ }^{22}$. Dari aspek perbedaan keyakinan inilah sehingga seorang kafir żimm $\grave{~ y a n g ~ m e m b u n u h ~ k a f i r ~ z ̇ i m m i ̄ ~ l a i n n y a ~ d i p i d a n a ~ m a t i . ~}$ Seorang kafir żimmī dipidana mati ketika ikut serta dalam pembunuhan yang dilakukan oleh seorang muslim terhadap kafir żimmī lainnya ${ }^{23}$. Jika seorang muslim membunuh orang Nasrani kemudian ia murtad, lalu ahli waris menuntut hukuman mati, maka dapat dikatakan bahwa orang yang dibunuh adalah orang kafir dan pembunuh tidak dapat dipidana karena perbuatannya, sebab ia membunuh orang kafir tersebut saat masih berstatus muslim. Untuk itu, ia tidak dijatuhi hukuman mati dan tidak pula diat. Jika ia bertobat, maka tobatnya diterima, dan jika tidak, maka ia dapat dibunuh karena murtad ${ }^{24}$. Sebagaimana Rasulullah saw. bersabda:

$$
25 \text { مَنْ بَدَّلَ دِينَهُ فَاقَتُُْوهُ (رواه البخاري) }
$$

Artinya:

Siapa yang mengganti agamanya, bunuhlah dia.

Yang dimaksud dengan mengganti agama adalah murtad atau keluar dari Islam, sehingga jika ia melakukan pembunuhan terhadap non muslim baik itu sebelum murtad maupun sesudahnya, maka tidak ada kisas baginya. Tetapi yang menjadi alasan ia untuk dibunuh adalah keluarnya ia dari Islam atau murtad.

\section{Sebab-sebab Perbedaan Pendapat}

Mengenai sebab-sebab perbedaan pendapat tentang kisas atau hukuman mati bagi pelaku pembunuhan terhadap non muslim yang dilakukan oleh seorang muslim, tentu saja masing-masing para ulama memiliki hujah dan dalil terhadap apa yang mereka kemukakan, baik itu nas dari Al-Qur'an, sunah maupun kias yang sudah tentu melalui ijtihad masing-masing. Adapun mayoritas ulama berpendapat bahwa tidak ada kisas bagi seorang muslim yang melakukan pembunuhan terhadap non muslim baik kafir harbī maupun kafir żimmī berdasarkan aspek perbedaan keyakinan. Oleh karena itu, salah satu syarat dilaksanakannya kisas adalah persamaan keyakinan. Pendapat ini merupakan pendapat jumhur ulama termasuk Imam al-Syāfi' '̄̄, yang berhujah pada hadis Rasulullah saw.

\footnotetext{
${ }^{21}$ Muḥammad bin Idrīs al-Syāfi' ’’, al-Umm, Jilid 6 (Beirut: Dār al-Ma'rifah, 1990), 40.

22 Muḥammad bin Idrīs al-Syāfi' '̄, al-Umm, 40.

${ }^{23}$ Syamsuddīn Muhammad bin Aḥmad bin 'Alī bin 'Abdul Khāliq, Jawāhir al- 'Uqūd wa Ma'̄̄n al-Quḍ̄h wa al-Mauqi'īn wa al-Syuhūd, Jilid 2, Cet. I (Beirut: Dār al-Kutub al-'Alamiyyah, 1996), 202.

${ }^{24}$ Muhammad bin Idrīs al-Syāfi' '⿳亠丷, al-Umm, 40.

${ }^{25}$ Muḥammad bin Ismā'īl Abu 'Abdullah al-Bukhārī al-Ju’fì, Șaḥ̄ḥ al-Bukhārī, 61.
} 


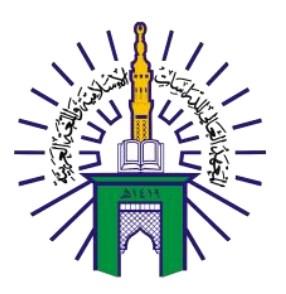

\section{BUSTANUL FUQAHA: \\ JURNAL BIDANG HUKUM ISLAM \\ Vol. 2 No. 1 (2021): Hal. 98-109 \\ EISSN: 2723-6021 \\ Website: https://journal.stiba.ac.id}

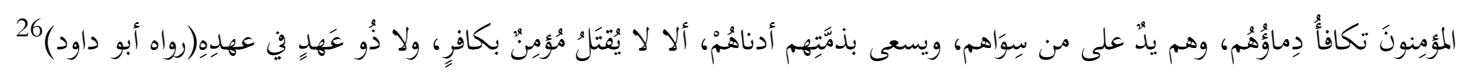

Artinya:

Kaum beriman itu sama darahnya. Yang paling rendah di antara mereka berusaha menuntut jaminan mereka. Dan mereka adalah satu tangan atas orang-orang selain mereka. Bahwa seorang mukmin tidak dihukum mati karena membunuh orang kafir dan janganlah membunuh orang kafir yang memiliki perjanjian damai dalam masa perjanjiannya yang masih berlaku.

Secara zahir hadis tersebut menyatakan dengan jelas bahwa seorang muslim tidak dikisas disebabkan membunuh orang kafir. Namun, Imam Abū Ḥanīfah mengemukakan pendapat yang berbeda dalam memahami hadis tersebut, bahwa orang kafir yang dimaksud adalah kafir harbi $\bar{l}$ atau orang kafir yang diperangi, bukan kafir $\dot{z} i m m \bar{\imath}$ atau orang kafir yang berlindung dibawah pemerintahan Islam ${ }^{27}$. Imam Abū Hanīfah juga mengambil dalil dari Al-Qur'an dalam surat Al-Māidah/5:45,

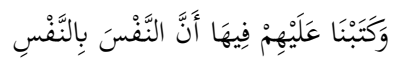

Terjemahnya:

"Dan Kami telah tetapkan terhadap mereka didalamnya (Taurat) bahwa nyawa (dibalas) dengan nyawa"28.

Syariat kisas juga berlaku dalam syariat Nabi Muhammad saw. termasuk pembunuhan maka balasannya dibunuh. Dan perlu diketahui, bahwa syariat terdahulu juga menjadi syariat bagi umat Islam selama tidak menyelisihinya, baik dalam hal nyawa, anggota badan maupun luka ${ }^{29}$. Pendapat Abū Hanīfah tentang seorang muslim yang dikisas karena membunuh seorang kafir żimmī berdasarkan dalil kias, bahwa tangan seorang muslim dipotong jika mencuri harta dari orang żimmī. Jika kehormatan hartanya sama dengan kehormatan harta kaum muslim, maka kehormatan darahnya sama dengan kehormatan darah kaum muslim ${ }^{30}$.

\section{KESIMPULAN}

Berdasarkan pembahasan mengenai perbedaan pendapat antara dua mazhab besar tersebut, yakni Imam Abū Ḥanīfah dan Imam al-Syāfí'̄ dalam perkara kisas atau hukuman mati yang diberlakukan kepada seorang muslim yang membunuh seorang non muslim, dapat diambil beberapa kesimpulan, yaitu:

1. Saat menetapkan sanksi hukum terhadap pelaku pembunuhan non muslim, Imam Abū Ḥanīfah memandang dari aspek persamaan dan kesetaraan, bahwa non muslim

\footnotetext{
${ }^{26}$ Abu Dāwud Sulaimān bin al-Asy'aṡ bin Ishāa al-Sijistān̄̄, Sunan Abī Dāwud, Juz 6, 587

${ }^{27}$ Abū Mālik Kamāl bin al-Sayyid Sālim, Saḥ̄ḥ Fiqh al-Sunnah wa Adillatuh wa Tawdīḥ Mażāhib al-A'immah, Jilid 4 (al-Qāhirah: al-Maktabah al-Tawfīqiyyah, 2003), 199-200.

${ }^{28}$ Kementerian Agama Republik Indonesia, 115.

${ }^{29}$ Abu Yahya Marwan bin Musa, Hidāyat al-Insān bi Tafsìr al-Qur'ān, 360.

${ }^{30}$ Muḥammad bin Aḥmad bin Rusyd al-Qurtubī, Bidāyat al-Mujtahid wa Nihāyat al-Muqtasid, 939.
} 

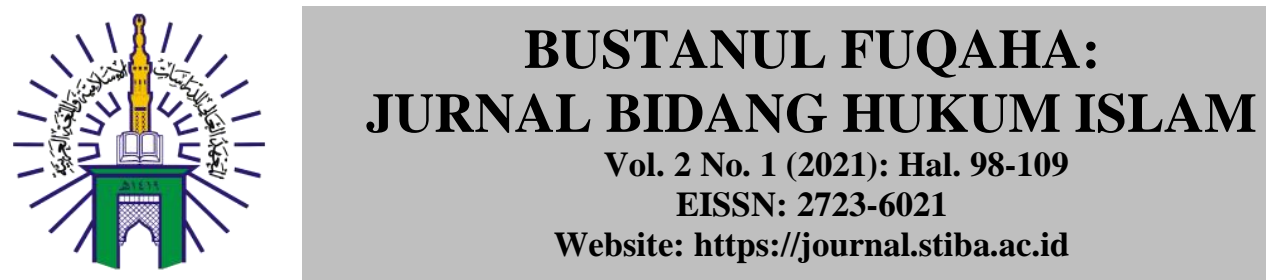

(żimmî) itu sama darahnya dengan orang muslim yakni sama dimata hukum. Apabila seorang muslim melakukan pembunuhan terhadap non muslim, maka ia dikenakan sanksi yang sama, yaitu kisas atau hukuman mati apabila dari pihak korban tidak memaafkan dan membayar diat apabila dimaafkan.

2. Imam al-Syāfi'ī memandang dari aspek keyakinan, apabila pelaku dan korban pembunuhan sama dalam keyakinan, maka berlaku bagi pelaku kisas atau hukuman mati dan membayar diat apabila dimaafkan. Adapun jika pelaku dan korban pembunuhan berbeda dalam keyakinan, maka tidak ada kisas yang diterapkan. Apabila seorang muslim melakukan pembunuhan terhadap non muslim secara sengaja, tidak ada kisas bagi pelaku pembunuhan. Namun, ia tetap dijatuhi hukuman selain dari hukuman mati berupa dipenjarakan dan tidak lebih dari satu tahun.

Adapun istinbat hukum dalam masalah ini, Imam Abū Ḥanīfah dan Imam alSyāfi' '̄ berbeda dalam memahami hadis Rasulullah saw. yang menyatakan bahwa seorang muslim tidak dibunuh karena membunuh orang kafir. Imam al-Syāfi' $1 \overline{1}$ memahami hadis tersebut secara zahir, sedangkan Imam Abū Hanīfah berpendapat bahwa yang dimaksud adalah kafir ḥarbī, bukan kafir żimmī. Imam al-Syāfi' '̄ juga berpendapat bahwa salah satu syarat diterapkannya kisas adalah kesetaraan dan persamaan. Sedangkan Imam Abū Hanīfah berpendapat dari segi kias bahwa seorang muslim yang mencuri harta orangorang non muslim, maka berlaku hukum potong tangan baginya, begitu pula jika melakukan pembunuhan maka hukuman sepadan yang diterapkan Abū Hanīfah.

\section{DAFTAR PUSTAKA}

A, Hajmy. Dimana Letak Negara Islam. Cet. I. Surabaya: P.T. Bina Ilmu, 1984.

Al-Bāri'̄̄, 'Us̉mān bin 'Alī bin Maḥjan; Fakhruddin al-Zayla'ī al-Hanafī, Tabȳ̄n alHaqāiq Syarḥu Kanz al-Daqāiq. Jilid 6. Cet. I; al-Qāhirah: al-Mathba'ah al-Kubrā al-Amīriyyah, $1313 \mathrm{H}$.

Al-Ju'fī, Muḥammad bin Ismā'īl Abu 'Abdullah al-Bukhārī, Șaḥ̄hh al-Bukhārī. Cet. I. Beirut: Dār Ṭūq al-Najāh, 2001.

Al-Qurtubī, Muḥammad bin Aḥmad bin Rusyd. Bidāyat al-Mujtahid wa Nihāyat alMuqtasid. Cet. I. al-Qāhirah: Dār al-'Ālamiyyah, 2016.

Al-Sa'dī, 'Abdurrahmān bin Nāṣir bin 'Abdullah. Taisīr al-Karìm al-Raḥmān fì Tafsīr

Kalām al-Mannān. Cet. I. Beirut: Muassasah al-Risālah, 2000.

Al-Ṣābūnī, Muhammad 'Alī, Rawāi' al-Bayān Tafsīr Āyāt al-Aḥkā., Juz 2. Cet. I. Damaskus: Maktabah al-Ghazālī, 1980.

Al-Sarkhasī, Muḥammad bin Aḥmad. al-Mabsūt, Jilid 26. Cet. I. Beirut: Dār al-Ma'rifah, 1993.

Al-Sijistān̄̄, Abu Dāwud Sulaimān bin al-Asy'as̉ bin Isḥāq, al-Marāsīl. Cet. I. Bairūt: Muassasah al-Risālah, 1408. 


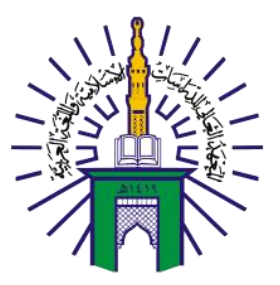

\section{BUSTANUL FUQAHA: \\ JURNAL BIDANG HUKUM ISLAM \\ Vol. 2 No. 1 (2021): Hal. 98-109 \\ EISSN: 2723-6021 \\ Website: https://journal.stiba.ac.id}

Al-Sijistān̄̄, Abu Dāwud Sulaimān bin al-Asy’aṡ bin Isḥāq. Sunan Abī Dāwud. Juz 6. Cet.

I. t.t.p.: Dār al-Risālah al-'Ālamiyyah, 2009.

Al-Syāfi'’̄, Muḥammad bin Idrīs. al-Umm. Jilid 6. Cet. I. Beirut: Dār al-Ma’rifah, 1990.

Kementerian Agama Republik Indonesia, Al-Qur'an Terjemah Perkata Asbabun Nuzul dan Tafsir Bil Hadis. Bandung: Semesta Al-Qur'an, 2013.

Khāliq, Syamsuddīn Muḥammad bin Aḥmad bin 'Alī bin 'Abdul. Jawāhir al- 'Uqūd wa Ma '̄in al-Qự̄ăh wa al-Mauqi'īn wa al-Syuhūd. Jilid 2. Cet. I. Beirut: Dār al-Kutub al-'Alamiyyah, 1996.

Musa, Abu Yahya Marwan bin. Hidāyat al-Insān bi Tafsīr al-Qur'ān. Jilid 1 (t.t.p.; t.t.).

Pilihan Para Ulama Tafsir, al-Tafsīr al-Muyassar. Cet. II. Saudi Arabia: Majma' al-Mulk Fahd li Ṭibā'ah al-Mușhaf al-Syarīf, 2009.

Sālim, Abū Mālik Kamāl bin al-Sayyid. Șah̄h Fiqh al-Sunnah wa Adillatuh wa Taw dịh Mażāhib al-A 'immah. Jilid 4. Cet. I. Kairo: al-Maktabah al-Tawfīqiyyah, 2003.

Shiddiqi, Hasbi. Pidana Mati dalam Syari'at Islam. Semarang: Pustaka Rizki Putra, 1998.

Soekanto, Soejono, dan Sri Mamudji, Penelitian Hukum Normatif: Suatu Tinjauan Singkat. Jakarta: Rajawali pers, 2001.

Soewadji, Jusuf. Pengantar Metodologi Penelitian. Jakarta: Mitra Wacana Media, 2012. 